\title{
ELECTRONIC MONITORING OF RUMINATION ACTIVITY AS AN INDICATOR OF HEALTH STATUS AND PRODUCTION TRAITS IN HIGH-YIELDING DAIRY COWS
}

\author{
András GÁSPÁRDY ${ }^{1 *}$, Gingis EFRAT ${ }^{1}$, Árpád Csaba BAJCSY ${ }^{2}$ and Sándor György FEKETE ${ }^{1}$ \\ ${ }^{1}$ Institute of Animal Breeding, Nutrition and Laboratory Animal Science, Faculty \\ of Veterinary Science, Szent István University, István u. 2, H-1078 Budapest, Hungary; \\ ${ }^{2}$ Large Animal Clinic Üllö, Faculty of Veterinary Science, Szent István University, Üllő, \\ Hungary
}

(Received 18 September 2013; accepted 25 June 2014)

\begin{abstract}
In view of the demonstrated relationship between rumination time and health status, the general welfare and metabolic condition of ruminants are often assessed by the examination of rumen function. The main goal of this study was to monitor the daily rumination activity (RA) and its connection with actual liveweight (LW), milk yield (MY) and with two diseases (subclinical hyperketonaemia SHK, uterine disease - UD) in 96 cows on the basis of a total of 1638 observations in Israel. The studied sample gave a highly significant response, showing that the selected diseases had a diminishing impact on RA and LW and no influence on MY. It can be concluded that the change of RA as determined by electronic monitoring, complemented by the change of LW, is a useful general indicator of health status and subclinical disease before the appearance of clinical signs.
\end{abstract}

Key words: Dairy cattle welfare, health status monitoring, subclinical hyperketonaemia, uterine disease, rumination activity

Recently the dairy industry has developed the 'Vocal Tag' (2010; referred to as Lely QWES-H/HR), which is a computerised rumination monitoring system providing information about the general health of cows (especially focusing on the existence of abomasal displacement, AD). The present study investigates the pattern of rumination activity to find a general indicator of the fresh cow's welfare and general health status, by comparing changes in the patterns of the rumination activity, milk production and liveweight on the course of 'healthy days' and 'ill days' within two given categories of pathological states (subclinical hyperketonaemia, SHK and uterine diseases, UD).

When cattle ingest feed, they do not chew solid particles intensively. Instead, processing of the feed is allocated to rumination, where rumen content is regurgitated in the form of boluses and masticated several before swallowed

*Corresponding author; E-mail: gaspardy.andras@aotk.szie.hu; Phone: 0036 (1) 478-4120; Fax: 0036 (1) 478-4120; Mobile: 0036 (20) 478-4437 
again. Ruminal movements serve four physiological functions: mixing and moving ingesta, eructation and regurgitation of ingesta for rumination. Lindström and Redbo (2000) showed that oral manipulation of feed serves a behavioural function too, irrespective of rumen load. A certain amount of rumination per day is important to give cattle an outlet for their natural behaviour. Individuals that are restricted in performing their behavioural needs may become frustrated and develop stereotypes such as tongue rolling or bar biting, which are signs of poor welfare.

Adult cattle ruminate approximately eight hours a day in 4 to 24 periods, each lasting 10 to 60 minutes. Functionally, rumen movements can be classified as primary and secondary cycles, plus regurgitation movements. The primary cycle mixes the ingested material within the rumen; it occurs every 1 to 2 minutes, and assists the passage of the content towards the omasum. The secondary cycle results in eructation and occurs at 1- to 2-minute intervals. The magnitude of the contractions and their form (primary or secondary ruminal motility, regurgitation or eructation) are related to the amount of coarse particles and the gases produced, which stretch the reticulum or the ruminal pillars (Blikslager et al., 2004).

During physical examination, rumen activity can be evaluated by different classical methods such as inspection, palpation, auscultation, percussion, ballottement, rectal examination, evaluation of the ruminal content or laparoscopy (Radostits, 2000). However, ruminal activity can also be evaluated indirectly by using a so-called 'Vocal Tag'. This tiny neck tag provides the farmer, on a daily basis, with online information regarding the rumen function of each individual cow, which serves as a very sensitive indicator of general well-being and health status. Changes in rumination activity are the earliest warning signs informing the veterinarian about potential health problems. Communication between the tags and the reader is based on an infrared beam. The Rumination Meter captures rumination time, chewing rhythm and the length of intervals between boluses.

Major factors influencing ruminal activity include the amount of feed ingested and the composition of the ration (Lindgren, 2009). Since chewing activity stimulates the secretion of saliva, which facilitates swallowing and contains high concentrations of bicarbonate and phosphate buffers that aid in buffering and sustaining the ruminal $\mathrm{pH}$ at a level suitable for microbial activity, which is physiologically 6.3 to 7.1 (Blikslager et al., 2004). The reduction of forage particle length shortens the time that cattle spend with chewing, increases ruminal acidity and the rate of content passage from the rumen, decreases fibre degradation and milk fat content (Beauchemin et al., 1997; Couderc et al., 2006). Significant differences in the duration of rumination were found between rations; excessive starch and easily fermentable carbohydrates in relation to the content of effective fibre stimulating rumination result in reduced chewing activity. Its consequence is a decreased saliva production and a drop in ruminal $\mathrm{pH}$, which alters fermentation patterns and predisposes cows to metabolic disturbances that negatively affect health status, well-being and production level (Lindgren, 2009). 
Differences in rumination activity have been reported between breeds (Welch et al., 1970) as well as body sizes (Bae et al., 1983), suggesting that animals with higher intake capacity require shorter time for chewing and ruminating. Regarding the aspect of housing, stocking density and grouping strategies play a significant role in rumination activity. Lying and resting behaviours are highly important for dairy cows to enable sufficient rumination time. Social stress, such as overcrowding and excessive competition for feed and free space, can significantly reduce rumination activity. Furthermore, increased lying time is also associated with reduced stress on feet and incidence of lameness, increased blood flow to the udder and stimulated feeding activity. Maximising lying time may ultimately reduce health costs, enhance productivity and improve cow welfare (Kai et al., 2009).

Ketosis, and even a high blood ketone body (acetone, acetoacetic acid and beta-hydroxybutyrate) level, is a serious metabolic problem typically occurring in dairy cows during early lactation characterised by intensive lipid mobilisation and a high glucose demand, and thereby a negative energy balance (NEB) in the background. Thus, severe energy deficit in the postpartum period may lead to clinical ketosis. Subclinical ketosis (increased concentration of ketone bodies in the blood) can be considered a preliminary phase of clinically detectable diseases and/or a factor predicting production and reproduction problems. The diagnosis of ketosis is based on the presence of risk factors (early lactation), clinical signs, ketone bodies in urine, blood or milk and the time that has elapsed since calving.

Cows are more resistant to uterine infections during oestrus, and as cows undergo more oestrous cycles after parturition, the prevalence of uterine diseases declines. This has led to the increased use of prostaglandin (PG) $F_{2 \alpha}$ or its analogues, at luteolytic doses, for the management of uterine disease (Kahn, 2005). Delayed involution is associated with autolysis of the placenta and may promote uterine infection. Bacterial proliferation in the uterine lumen and the release of toxins lead to metritis. Sheldon et al. (2006) classified various forms of postpartum uterine diseases. More recently, physiological changes in the patterns of uterine contractility have been quantified (Bajcsy et al., 2005). Risk factors, such as milk fever (Risco et al., 1994), high milk production, negative energy balance (Butler, 1997) or uterine infections (Mateus et al., 2002) have frequently been reported to be responsible for, or occurring simultaneously with, a delayed uterine involution and a prolonged interval to the first postpartum ovulation.

\section{Materials and methods}

Data were collected over a two-year period (2008 and 2009) from three typical farms in Israel. All cows diagnosed with SHK and/or with UD were selected for the investigation. The 96 cows included in the database represented 182 individual cases (due to repeated occasions according to lactations and mul- 
tiple disorders). Of them, 20 had subclinical ketosis and 84 had uterine disease, and there were altogether 1638 records by trait. Feeding was based on total mixed ration (TMR) supplied by a central producer. In general, high-quality silage comprises over $90 \%$ of the forage in dairy cows and high-quality silage and haylage collectively make up approximately $50 \%$ of the total dry matter. In the cases presented here, the concentrate consisted mainly of maize $(55 \%)$ and barley $(10 \%)$ meals; the other ingredients were maize distillers' grain $(5 \%)$, full-fat soybean $(10 \%), 4 \%$ canola meal (extracted solvent), which are rich in protein, plus $16 \%$ mineral-vitamin premix (Table 1). The proposed energy concentration for lactating cows is $7.3-7.5 \mathrm{MJ} \mathrm{NE}_{\mathrm{l}} / \mathrm{kg}$ dry matter (DM), with $17-17.5 \%$ crude protein and an undegradable intake protein (UIP) of $35 \%$. The optimal neutral detergent fibre (NDF) level is $30-34 \%$ of the dry matter. The recommendations of the National Research Council (2001) were used.

Cows in this study were milked three times a day by an Astronaut milking robot produced by Lely Industries along with the QWES-HR monitoring system under loose housing system.

The following data were collected from the monitoring system (via the T4C software): days in milk, daily rumination activity (RA), daily liveweight (LW), daily milk yield (MY), as well as ID number of cow, calving date, number of lactations and the date of RA/LW/MY recording. The medical records were collected from a NOAH software used for medical registration, and included the name of disease and the date of disease diagnosis (0-day). The animals were classified as ill during their 'ill period of time', which included three days: the day of disease diagnosis and the \pm 1 day around that day. Animals were classified as healthy during a preceding and a succeeding period of time farther from the day of diagnosis (on day $-6,-5,-4$ and $4,5,6$, respectively). For the data analysis single trait mixed hierarchical linear models (package 'nlme'; Pinheiro et al., 2013) of the R software for statistical computing (R Core Team, 2013) were used.

Basic model in the case of SHK:

$\mathrm{Y}_{\text {iklmnop }}=\mu+\mathrm{H}_{\mathrm{i}}+\mathrm{L}_{\mathrm{k}}+\mathrm{Y}_{1}+\mathrm{S}_{\mathrm{m}}+\mathrm{F}_{\mathrm{n}} / \mathrm{C}_{\mathrm{o}} / \mathrm{O}_{\mathrm{p}}+\mathrm{e}_{\mathrm{iklmnop}}$,

basic model in the case of UD:

$\mathrm{Y}_{\mathrm{ij} k \mathrm{mop}}=\mu+\mathrm{H}_{\mathrm{i}}+\mathrm{P}_{\mathrm{j}}+\mathrm{H}_{\mathrm{i}}: \mathrm{P}_{\mathrm{j}}+\mathrm{L}_{\mathrm{k}}+\mathrm{P}_{\mathrm{j}}: \mathrm{L}_{\mathrm{k}}+\mathrm{Y}_{1}+\mathrm{S}_{\mathrm{m}}+\mathrm{C}_{\mathrm{o}} / \mathrm{O}_{\mathrm{p}}+\mathrm{e}_{\mathrm{ij} k \mathrm{klmop}}$

where

$\mathrm{Y}_{\mathrm{ijk} k \mathrm{mnop}}=$ the value of one of the traits (RA, LW and MY),

$\mu=$ the mean value of one of the traits (RA, LW and MY),

$\mathrm{H}_{\mathrm{i}}=$ fixed effect of health status periods ( 3 ; the preceding and succeeding healthy periods and the ill period),

$\mathrm{P}_{\mathrm{j}}=$ the fixed effect of the lactation phase $(3 ; 1=$ from day 1 up to day 100,2 = from day 101 up to day 200,3 = from day 200 onwards; used in the model for UD only, because of a continuous presence of UD in a lactation), 
$\mathrm{H}_{\mathrm{i}}: \mathrm{P}_{\mathrm{j}}=$ health status period by lactation phase interaction,

$\mathrm{L}_{\mathrm{k}}=$ the fixed effect of parturition category $(2 ; 1=$ primiparous cows, $2=$ pluriparous cows),

$\mathrm{P}_{\mathrm{j}}: \mathrm{L}_{\mathrm{k}}=$ lactation phase interaction by parturition category interaction,

$Y_{1}=$ the fixed effect of year $(2,1=2008,2=2009)$,

$\mathrm{S}_{\mathrm{m}}=$ the fixed effect of season $(2 ; 1=$ winter: from October to March, $2=$ summer: from April to September),

$F_{n}=$ the random effect of farm (used in the model for SHK only, where, however, its effect was statistically not significant),

$\mathrm{C}_{\mathrm{o}}=$ the random effect of cow nested within the random effect of farm $\left(\mathrm{F}_{\mathrm{n}}\right)$,

$\mathrm{O}_{\mathrm{p}}=$ individual no. of repeated occasion of the disease, nested within random effects of cow $\left(\mathrm{C}_{\mathrm{o}}\right)$ and farm $\left(\mathrm{F}_{\mathrm{n}}\right)$,

$\mathrm{e}_{\mathrm{ijk} k \mathrm{mnop}}=$ the random residual.

The Statistica software (Statsoft Inc., 2013) was applied for the preparation of data and for the graphical presentation of the daily pattern of RA, LW and MY, as well as for calculating the average and the median of the day of diagnosis.

Table 1

Natural ingredients of the cows' daily ration ( $\mathrm{kg}$, average of the studied farms, mean body weight $700 \mathrm{~kg}$, for $3.3 \%$ fat corrected milk)

\begin{tabular}{lccccc}
\hline Raw materials & $\begin{array}{c}\text { Fresh } \\
\text { cows }\end{array}$ & $\begin{array}{c}\text { Mid-lactation } \\
\text { cows }\end{array}$ & $\begin{array}{c}\text { Late lactation } \\
\text { cows }\end{array}$ & $\begin{array}{c}\text { Dry } \\
\text { cows }\end{array}$ & $\begin{array}{c}\text { Antepartum } \\
\text { cows }\end{array}$ \\
\hline Maize silage & 15 & 19 & 22 & 12 & 13 \\
Lucerne haylage & 2 & 3 & 3 & - & - \\
Meadow hay, chopped & - & - & - & - & - \\
Lucerne hay, chopped & 3.5 & 3 & 2 & - & - \\
Lucerne, chopped & 0.5 & 2 & 3 & - & - \\
Citrus peel, wet & 2 & 3 & - & - & - \\
Sugar beet pulp, dry & 0.5 & - & - & - & - \\
Brewer's grain, wet & 0.5 & 1 & 3 & - & - \\
Maize gluten meal & 3 & 2 & 0.5 & - & 1.5 \\
Whey, liquid & 5 & 4 & 7 & - & 0.5 \\
Molasses $_{\text {Concentrate }}^{\mathrm{x}}$ & 0.5 & 0.5 & 0.5 & - \\
Wheat bran $^{\mathrm{xx}}$ & 6 & 9 & 0.5 & & - \\
\hline
\end{tabular}

Fresh cows $=$ from calving to 30 days post partum, with an average daily milk production of $45 \mathrm{~kg}$; mid-lactation cows = from day 31 to day 200 after calving, with an average daily milk production of $40 \mathrm{~kg}$; late lactation cows = from day 201 to drying off, with an average daily milk production of $30 \mathrm{~kg}$; dry cows = first 6 weeks of the dry period; antepartum cows = last 2 weeks of the dry period. ${ }^{x}$ Concentrate: $55 \%$ maize, $10 \%$ barley, $5 \%$ maize distillers' grain, $10 \%$ full fat soybean, $4 \%$ canola meal, extracted solvent, $16 \%$ mineral-vitamin premix. ${ }^{\mathrm{xx}}$ Wheat bran with 10,000 IU of vitamin A and 20 IU of vitamin E 
The results provide the least squares means (LSM), their standard error (SEM), as well as the P value. In the case of SHK the results of the three investigated parameters (RA, LW and MY) are presented by health status period. Because of the significant interactions $\left(\mathrm{H}_{\mathrm{i}}: \mathrm{P}_{\mathrm{j}}\right.$ as well as $\left.\mathrm{P}_{\mathrm{j}}: \mathrm{L}_{\mathrm{k}}\right)$ in the case of UD the results are further detailed by parturition category and lactation phase. In addition, the deviations (which are the differences between the mean of ill days and the mean of the two healthy periods) are also shown to estimate the expectable changes in ill cows. These were proven statistically by the Tukey method (adjusted $\mathrm{P}$ values were reported). Residuals of the models were checked visually for normality and constant variance, model appropriateness and influential points.

\section{Results}

Patterns of the healthy days for RA, LW and MY in the sample are shown in Fig. 1. During early lactation a gradual recovery of RA can be clearly identified, along with an increased milk production which peaks at approximately $40 \mathrm{~kg}$. In this period, the average liveweight in the herd remains unchanged, because the gain in heifers equalises the losses of cows. During mid-lactation, RA together with the milk production begins to drop slightly but tendentiously. However, this is a beneficial phase of lactation when all the cows can continue their weight gain. At the end of lactation RA decreases further by day 305, approaching its initial value. Milk production decreases remarkably in this phase. Cows generally stop growing by the time of drying off.

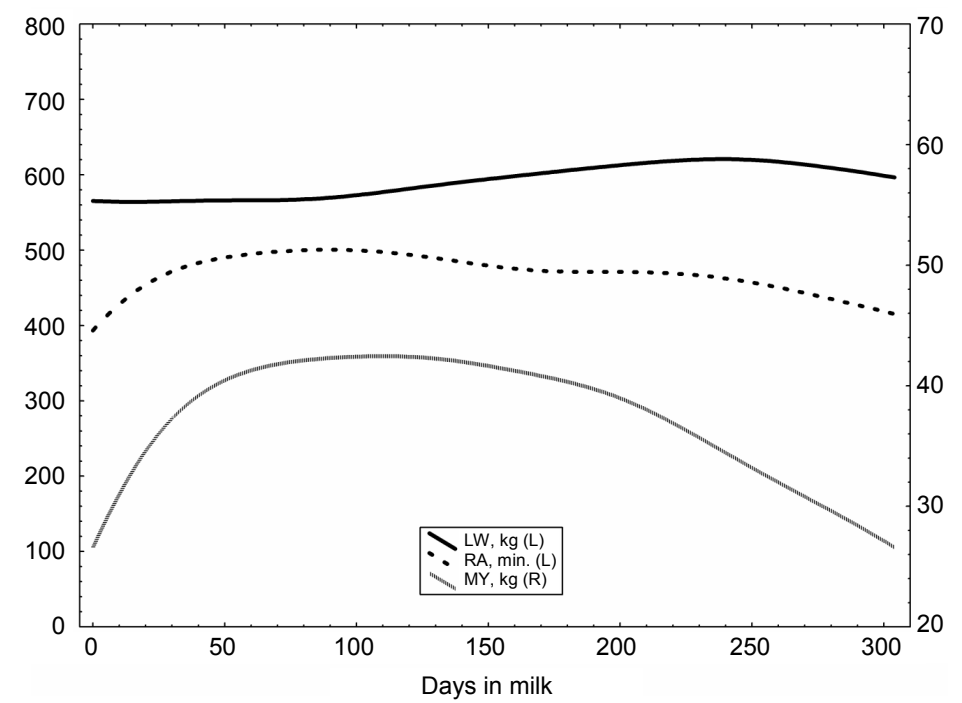

Fig. 1. Patterns of daily rumination activity (RA), liveweight (LW) and milk yield (MY) of the healthy days during the 305 days of lactation (distance-weighted line fitting on raw records) 
The average time of disease occurrence in the case of subclinical hyperketonaemia and uterine disease was day 54 (median: day 14) and 73 (median: day 19), respectively.

In the case of SHK (Table 2) the values in the preceding and succeeding healthy periods provide information about typical physiological alterations of the self-sacrificing dairy cows at the beginning of lactation: a remarkable increase in rumination activity (feed intake) and in milk production with a simultaneous loss in body weight (all alterations were statistically significant, $\mathrm{P}<0.05$ ). Here, all deviations appeared to be negative; however, only the change in rumination activity was significant $(-64.3 \mathrm{~min}, \mathrm{P}<0.01)$.

Table 2

Comparison of least squares means (LSM) in case of subclinical hyperketonaemia (SHK) by health status periods

\begin{tabular}{|c|c|c|c|c|c|c|c|}
\hline \multirow{3}{*}{ Periods/deviation } & \multirow{3}{*}{$\begin{array}{l}\text { No. of } \\
\text { records }\end{array}$} & \multicolumn{6}{|c|}{ Subclinical hyperketonaemia (SHK) } \\
\hline & & \multicolumn{2}{|c|}{ RA, min. } & \multicolumn{2}{|c|}{ LW, kg } & \multicolumn{2}{|c|}{ MY, kg } \\
\hline & & LSM & (SEM) & LSM & (SEM) & LSM & (SEM) \\
\hline Preceding healthy period & 63 & $392^{\mathrm{a}}$ & $(23.5)$ & $595^{\mathrm{b}}$ & $(16.6)$ & $27.5^{\mathrm{a}}$ & $(2.41)$ \\
\hline Days around diagnosis & 63 & $361^{\mathrm{a}}$ & (19.6) & $575^{\mathrm{a}}$ & (16.4) & $29.5^{\mathrm{a}}$ & $(2.26)$ \\
\hline Succeeding healthy period & 63 & $459^{\mathrm{b}}$ & (19.4) & $566^{\mathrm{a}}$ & (16.4) & $34.6^{\mathrm{b}}$ & $(2.25)$ \\
\hline Deviation $^{1}$ & 189 & $-64.3^{* *}$ & $(21.4)$ & -5.76 & $(4.31)$ & -1.57 & (1.68) \\
\hline
\end{tabular}

a,b,c - different superscript letters show significant $(\mathrm{P}<0.05)$ differences; ${ }^{1}-\mathrm{P}$ values are adjusted using the Tukey method for means of healthy and ill days $\left({ }^{* *} \mathrm{P}<0.01\right)$; RA $=$ daily rumination activity; LW = daily liveweight; MY = daily milk yield

In the case of UD (Table 3) these values reflect the same proven physiological situation (also in all the traits, $\mathrm{P}<0.05$ ) within the first lactation phase independently of the parturition categories of cows. However, the later alterations of the traits remained insignificant. The drop in liveweight of the firstcalving UD cows $(-4.80 \mathrm{~kg}, \mathrm{P}<0.05)$ was not followed by a significant reduction of the minutes spent by rumination. In contrast to this, the statistically significant $(-43.7, \mathrm{P}<0.01)$ negative deviation in RA was no accompanied by an essential drop of liveweight in pluriparous cows.

\section{Discussion}

It is generally known that a typical dairy cow reaches the peak of milk production between 4 and 6 weeks after calving. The present findings fit well with this observation (see Fig. 1). Dry matter intake lags behind, physiologically peaking around 9 to 11 weeks. This situation puts the cow in a NEB in the first phase of 


\section{Table 3}

Comparison of least squares means (LSM) in case of uterine disease (UD) by health status periods, by lactation phase and by parturition category

\begin{tabular}{|c|c|c|c|c|c|c|c|}
\hline \multirow{3}{*}{ Periods/deviation } & \multirow{3}{*}{$\begin{array}{l}\text { No. of } \\
\text { records }\end{array}$} & \multicolumn{6}{|c|}{ Uterine disease (UD) } \\
\hline & & \multicolumn{2}{|c|}{$\mathrm{RA}, \min }$. & \multicolumn{2}{|c|}{ LW, kg } & \multicolumn{2}{|c|}{ MY, kg } \\
\hline & & LSM & (SEM) & LSM & (SEM) & LSM & (SEM) \\
\hline In primiparous cows & & & & & & & \\
\hline $\begin{array}{l}\text { In first lactation phase } \\
\text { Preceding healthy period } \\
\text { Days around diagnosis } \\
\text { Succeeding healthy period } \\
\text { Deviation }^{1}\end{array}$ & $\begin{array}{l}114 \\
114 \\
114 \\
342\end{array}$ & $\begin{array}{c}368^{\mathrm{a}} \\
432^{\mathrm{b}} \\
470^{\mathrm{c}} \\
13.4\end{array}$ & $\begin{array}{l}(17.2) \\
(16.7) \\
(17.1) \\
(11.9)\end{array}$ & $\begin{array}{l}530^{\mathrm{b}} \\
519^{\mathrm{a}} \\
518^{\mathrm{a}} \\
-4.80^{*}\end{array}$ & $\begin{array}{l}(8.72) \\
(8.68) \\
(8.69) \\
(1.99)\end{array}$ & $\begin{array}{r}23.8^{\mathrm{a}} \\
27.3^{\mathrm{b}} \\
30.2^{\mathrm{c}} \\
0.25\end{array}$ & $\begin{array}{l}(1.48) \\
(1.46) \\
(1.46) \\
(0.57)\end{array}$ \\
\hline $\begin{array}{l}\text { In second lactation phase } \\
\text { Preceding healthy period } \\
\text { Days around diagnosis } \\
\text { Succeeding healthy period } \\
\text { Deviation }^{1}\end{array}$ & $\begin{array}{l}14 \\
14 \\
14 \\
42\end{array}$ & $\begin{array}{l}490 \\
510 \\
528 \\
0.66\end{array}$ & $\begin{array}{l}(34.7) \\
(34.3) \\
(35.4) \\
(25.8)\end{array}$ & $\begin{array}{l}546 \\
549 \\
552 \\
-0.36\end{array}$ & $\begin{array}{c}(11.20) \\
(11.17) \\
(11.27) \\
(4.43)\end{array}$ & $\begin{array}{l}36.4 \\
35.9 \\
35.6 \\
-0.07\end{array}$ & $\begin{array}{l}(2.74) \\
(2.73) \\
(2.76) \\
(1.27)\end{array}$ \\
\hline $\begin{array}{l}\text { In third lactation phase } \\
\text { Preceding healthy period } \\
\text { Days around diagnosis } \\
\text { Succeeding healthy period } \\
\text { Deviation }^{1}\end{array}$ & $\begin{array}{r}8 \\
8 \\
8 \\
24\end{array}$ & $\begin{array}{l}434 \\
444 \\
451 \\
1.57\end{array}$ & $\begin{array}{l}(18.4) \\
(18.5) \\
(19.2) \\
(13.3)\end{array}$ & $\begin{array}{l}587 \\
586 \\
587 \\
-0.36\end{array}$ & $\begin{array}{l}(8.89) \\
(8.90) \\
(8.95) \\
(2.27)\end{array}$ & $\begin{array}{c}30.2 \\
30.9 \\
30.2 \\
0.66\end{array}$ & $\begin{array}{l}(1.58) \\
(1.58) \\
(1.60) \\
(0.65)\end{array}$ \\
\hline In pluriparous cows & & & & & & & \\
\hline $\begin{array}{l}\text { In first lactation phase } \\
\text { Preceding healthy period } \\
\text { Days around diagnosis } \\
\text { Succeeding healthy period } \\
\text { Deviation }^{1}\end{array}$ & $\begin{array}{l}231 \\
231 \\
231 \\
693\end{array}$ & $\begin{array}{l}431^{\mathrm{a}} \\
425^{\mathrm{a}} \\
506^{\mathrm{b}} \\
-43.7^{* *}\end{array}$ & $\begin{array}{l}(15.9) \\
(15.5) \\
(15.5) \\
(12.7)\end{array}$ & $\begin{array}{c}613^{\mathrm{c}} \\
603^{\mathrm{b}} \\
598^{\mathrm{a}} \\
-2.39\end{array}$ & $\begin{array}{l}(8.95) \\
(8.93) \\
(8.93) \\
(1.71)\end{array}$ & $\begin{array}{l}35.3^{\mathrm{a}} \\
37.6^{\mathrm{b}} \\
41.8^{\mathrm{c}} \\
-1.00\end{array}$ & $\begin{array}{l}(1.37) \\
(1.34) \\
(1.34) \\
(0.67)\end{array}$ \\
\hline $\begin{array}{l}\text { In second lactation phase } \\
\text { Preceding healthy period } \\
\text { Days around diagnosis } \\
\text { Succeeding healthy period } \\
\text { Deviation }^{1}\end{array}$ & $\begin{array}{r}39 \\
39 \\
39 \\
117\end{array}$ & $\begin{array}{l}500 \\
467 \\
478 \\
-21.7\end{array}$ & $\begin{array}{l}(37.3) \\
(38.9) \\
(38.9) \\
(32.4)\end{array}$ & $\begin{array}{l}597 \\
596 \\
602 \\
-3.11\end{array}$ & $\begin{array}{l}(13.2) \\
(13.3) \\
(13.3) \\
(4.35)\end{array}$ & $\begin{array}{l}43.8 \\
42.2 \\
42.1 \\
-0.77\end{array}$ & $\begin{array}{l}(3.03) \\
(3.09) \\
(3.09) \\
(1.70)\end{array}$ \\
\hline $\begin{array}{l}\text { In third lactation phase } \\
\text { Preceding healthy period } \\
\text { Days around diagnosis } \\
\text { Succeeding healthy period } \\
\text { Deviation }^{1}\end{array}$ & $\begin{array}{l}33 \\
33 \\
33 \\
99\end{array}$ & $\begin{array}{l}464 \\
438 \\
452 \\
-19.8\end{array}$ & $\begin{array}{l}(25.4) \\
(25.4) \\
(25.9) \\
(21.5)\end{array}$ & $\begin{array}{l}637 \\
636 \\
634 \\
0.28\end{array}$ & $\begin{array}{l}(10.6) \\
(10.6) \\
(10.6) \\
(2.88)\end{array}$ & $\begin{array}{c}32.1 \\
31.7 \\
31.2 \\
0.07\end{array}$ & $\begin{array}{l}(2.07) \\
(2.07) \\
(2.09) \\
(1.13)\end{array}$ \\
\hline
\end{tabular}

a,b,c - different superscript letters show significant $(\mathrm{P}<0.05)$ differences; ${ }^{1}-\mathrm{P}$ values are adjusted using the Tukey method for means of healthy and ill days $\left({ }^{*} \mathrm{P}<0.05,{ }^{* *} \mathrm{P}<0.01\right)$; RA $=$ daily rumination activity, $\mathrm{LW}=$ daily liveweight, $\mathrm{MY}=$ daily milk yield 
lactation. Cows use body fat reserves to cover the shortfall. Therefore an average healthy cow can be expected to lose between $0.5-1 \mathrm{~kg}$ per day during the first 60-80 days in milk. According to Agnew et al. (1996), primiparous cows use nutrients for weight gain rather than milk production as opposed to pluriparous cows that rather lose weight at the beginning of lactation at the expense of high milk yield. Due to the fact that Fig. 1 takes into consideration the whole sample, regardless of primiparous or pluriparous cows, the expected pattern of liveweight at the beginning of lactation cannot be observed. However, it became obvious that also the heifers diagnosed with UD showed a reduction of body weight after their first delivery (Table 2).

At around day 90 or at beginning of the second phase of lactation, energy intake can satisfy the declining energy demand for milk. During mid-lactation, at approximately 180 days in milk, cows replenish their body fat reserves lost in early lactation. In late lactation the body condition score (BCS) of an average cow should approach 3.5. Cows in early lactation consume approximately $10 \%$ less DM than cows at the same level of production in mid-lactation. The lower feed intake with a decreasing concentrate to forage ratio of the ration may explain the slight reduction of rumination activity over the last third of the lactation period (Fig. 1). A disease can be typical of a certain stage of lactation: subclinical ketosis is most frequently observed during the post-calving period or in early lactation (Demelash et al., 2005). The postparturient period is also a typical time for the occurrence of metritis (Kahn, 2005).

Ketonaemic cows show a moderate drop in milk production in order to minimise the pathologic energy deficiency (Fleming, 2002). This phenomenon confirms the suggestion that ketosis can be a 'self-limiting ailment'. Especially in high-producing Holstein cows, it is of high probability that body reserves are depleted after calving, resulting in ketonaemia and/or 'underfeeding ketosis'. At the beginning of lactation, the LW of pluriparous cows shows a pronounced decreasing pattern due to the pre-existing physiological NEB, while milk production and rumination activity show a normal increasing pattern. Moallem et al. (2002) reported the decrease in concentrate consumption as an indication of reduced appetite during severe uterine disease, which explains the drop in rumination activity and body weight of pluriparous cows, as it could be seen in this study.

The present study shows a strong connection between the cows' health condition and rumination activity. In fact, in both pathological states investigated the cows showed a significant drop in daily RA (SHK and UD) and in LW (UD). A crucial alteration in MY was not detectable in this sample. The above relationship emphasises the importance of monitoring rumination activity for diagnostic purposes and enables veterinarians and the dairy farm management to intervene early. It can be concluded that the change of RA as determined by electronic monitoring, complemented by the change of LW, is a useful indicator of subclinical hyperketonaemia and uterine disease before the appearance of clinical signs. 
Many factors may have influenced the results of this study, such as the relatively small number of cows included and the not totally perfect match between the day of disease diagnosis and the day of lowest rumination activity. This could be due to the fact that the responsible veterinarian did not visit the farm on a daily basis and, thus, it could occur that a cow showed a decline in rumination activity prior to diagnosis. Moreover, the disease conditions were measured over a random period of three days, while the rest of the days around that period were regarded as healthy, although some diseases might have a longer course which may alter the numbers of 'healthy' days.

Most control programmes focus on disease prevention and good management practices, which are more cost effective than treatment. Therefore, the use of RA as an indicator also provides an animal welfare benefit. Nowadays, a growing number of farms utilise electronic rumination monitoring technology in order to forecast the need for intervention in management or health care. Monitoring and tracking rumination activity may provide essential information, including mainly changes in feeding quality, voluntary feed intake, grazing quality and quantity, metabolic processes, weather influence and the presence of diseases influencing a cow's appetite. Thus, in order to maximise the usefulness of rumination activity as a prediction tool, further research is necessary, using a larger sample size. This study focused on diseases other than abomasal displacement which has been in the centre of this technology until now. Future research should also aim at investigating the interrelationship between rumination activity and the occurrence of other diseases.

\section{Acknowledgements}

The authors thank Lely Industries and particularly Mr. Rik Van Der Tol and Mr. Arjen Van Der Kamp for their assistance with gathering suitable farms, collecting the data for this study as well as being continuously available for all questions. The authors also owe thanks to the farmers Mr. David Peri (Moshav Gilat), Mr. Yaqov Koren (Moshav HaYogev) and Mr. Erez Slaw (Moshav Nitzanei Oz), who were ready to share their farm business information and assist in any question during the study period.

\section{References}

Agnew, K. W., Mayne, C. S. and Doherty, J. G. (1996): An examination of the effect of method and level of concentrate feeding on milk production in dairy cows offered a grass silagebased diet. Anim. Sci. 63, 21-31.

Bae, D. H., Welch, J. G. and Gilman, B. E. (1983): Mastication and rumination in relation to body size in cattle. J. Dairy Sci. 66, 2137-2141.

Bajcsy, Á. Cs., Szenci, O., Doornenbal, A., van der Weijden, G. C., Csorba, Cs., Kocsis, L., Szücs, I., Ostgard, S. and Taverne, M. A. M. (2005): Characteristics of bovine early puerperal uterine contractility recorded under farm conditions. Theriogenology 64, 99-111. 
Beauchemin, K. A., Rode, L. M. and Elison, M. V. (1997): Chewing activities and milk production of dairy cows fed alfalfa as hay, silage or dried cubes of hay or silage. J. Dairy Sci. 80, 324-333.

Blikslager, A. T., Jones, S. L., Grondahl, M-L., Merritt, A. M. and Malbert, C. H. (2004): Pathophysiology of the gastrointestinal tract. In: Dunlop, R. H. and Malbert, C. H. (eds) Veterinary Pathophysiology. Blackwell, Oxford, UK. pp. 111-142.

Butler, W. R. (1997): Review: Effect of protein nutrition on ovarian and uterine physiology in dairy cattle. J. Dairy Sci. 81, 2533-2539.

Couderc, J. J., Rearte, D. H., Schroeder, G. F., Ronchi, J. I. and Santini, F. J. (2006): Silage chop length and hay supplementation on milk yield, chewing activity, and ruminal digestion by dairy cows. J. Dairy Sci. 89, 3599-3608.

Demelash, B., Etana, D. and Fekadu, B. (2005): Prevalence and risk factors of mastitis in lactating dairy cows in Southern Ethiopia. Intern. J. Appl. Res. Vet. Med. 3, 189-198.

Fleming, S. A. (2002): Ketosis of ruminants (acetonaemia). In: Smith, B. P. (ed.) Large Animal Internal Medicine. Third edition. Mosby, Inc., St. Louis, Missouri. pp. 1241-1247.

Kahn, C. M. (2005): The Merck Veterinary Manual. Merck \& Co. Inc., NJ. http://www.merckvetmanual. com. Retrieved on 21 February 2010.

Kai, Y., Zong-Ping, L. and Zong-Yuan, W. (2009): Applying dairy cow behavior in management practice. J. Northeast Agric. Univ. 16, 86-92.

Lely QWES-H/HR: Infrared detection system. http://www.lely.com/brochures/brochures_pdf/dairy/ lely-qwes h-en.pdf. Retrieved on 20 April 2010.

Lindgren, E. (2009): Validation of rumination measurement equipment and the role of rumination in dairy cow time budgets. University of Agricultural Sciences Uppsala. http://stud.epsilon. slu.se/629/1/Lindgren_e_091120.pdf. Retrieved on 21 February 2010.

Lindström, T. and Redbo, I. (2000): Effect of feeding duration and rumen fill on behavior in dairy cows. Appl. Anim. Behav. Sci. 70, 83-97.

Mateus, L., da Costa, L. L., Bernardo, F. and Silva, J. R. (2002): Influence of puerperal uterine infection on uterine involution and postpartum ovarian activity in dairy cows. Reprod. Domest. Anim. 37, 31-35.

Moallem, U., Gur, P., Shpigel, N., Maltz, E., Livshin, N., Yacoby, S., Antman, A. and Aizinbud, E. (2002): Graphic monitoring of the course of some clinical conditions in dairy cows using a computerized dairy management system. Isr. J. Vet. Med. 57, 43-64.

National Research Council (2001): Nutrient Requirements of Dairy Cattle. Seventh revised edition. National Academy Press, Washington, D.C.

Pinheiro, J., Bates, D., DebRoy, S., Sarkar, D. and the R Development Core Team (2013): NLME: Linear and Nonlinear Mixed Effects Models. R package version 3.1-113.

Radostits, O. M. (2000): 17.3. Clinical examination of digestive tract and abdomen. In: Radostits, O. M., Mayhew, I. G. J. and Houston, D. M. (eds) Veterinary Clinical Examination and Diagnosis. W. B. Saunders, London, UK. pp. 415-457.

R Core Team (2013): R: A language and environment for statistical computing. R Foundation for Statistical Computing, Vienna, Austria. URL http://www.R-project.org/

Risco, C. A., Drost, M., Thatcher, W. W., Savio, J. and Thatcher, M. J. (1994): Effects of calvingrelated disorders on prostaglandin, calcium, ovarian activity and uterine involution in postpartum dairy cows. Theriogenology 42, 183-203.

Sheldon, I. M., Lewis, G. S., LeBlanc, S. and Gilbert, R. O. (2006): Defining postpartum uterine disease in cattle. Theriogenology $65,1516-1530$.

StatSoft, Inc. (2013): STATISTICA (data analysis software system), version 12. www.statsoft.com.

Welch, J. G., Smith, A. M. and Gibson, K. S. (1970): Rumination time in four breeds of dairy cattle. J. Dairy Sci. 53, 89-91. 